\title{
Nie uit my duim gesuig nie, op my erewoord
}

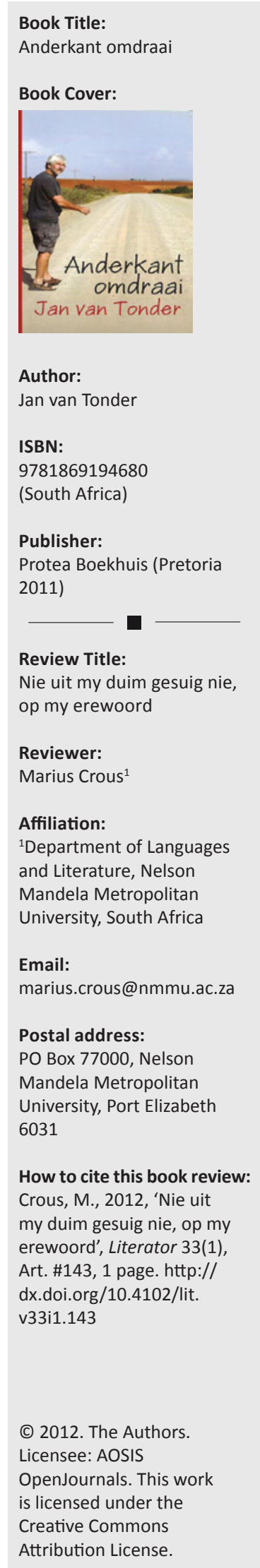

Die titel van my resensie is ontleen aan een van die tekste in hierdie bundel. En dis wat die leser kry: 'kort-kortverhale, essays, sketse en anekdotes' (op die agterflap) te make met 'n outobiografiese verteller wat sy eie verhale vertel of verhale oor sy vriende of kennisse of mense met wie hy te doen gekry het.

Die aanslag van die tekste is onpretensieus, soos wat die leser verwag van materiaal wat oorspronklik in Rapport se tydskrifbylae verskyn het. Dit bied fyn beskrywings en waarnemings van interessante figure en hulle doen en late, meestal met deernis gedoen. Baie van die tekste is tragikomies. Van Tonder se tekste het soms ook die probleem wat 'n mens by vertellinge van hierdie aard kry, naamlik dat die slot afgewater en onaf voorkom. Dit is jammer, want die leser word aan die begin met retoriese vaardigheid betrek by die vertellinge met, byvoorbeeld, 'Lank, lank gelede was 'n spesifieke dag'; of 'Lank laas iets van jou gelees'; 'Kom ons noem hom Regardt Opperman' en 'In elke dorp weet iedereen altyd ...' - om maar enkeles te noem.

Uit hierdie bundel kan die leser 'n beeld rekonstrueer van iemand wat eenvoudig dog gelukkig grootgeword het, wat nie besonder lief was vir skoolwerk nie, maar wat toe hy die letterkunde en die woord ontdek het, sy doel in die lewe besef het en begin het om ernstig te skryf.

Van Tonder beeld manlikheid ook op ' $n$ interessante wyse uit - spesifiek die middeljarige man se doen en late in Suid-Afrika na 1994. In die verhaal 'Die helm' word goedig gespot met ' $n$ vriend se maklike aanknoop en beëindiging van verhoudings. By monde van die verteller in 'Is dit die dogter of die ma?' word juis verontskuldigend gesê dat 'synde [hy] in sonde ontvang en gebore [is], en sonder dat [hy] dit bewustelik wil' hy hom geroepe voel om die vrou in haar nood by te staan.

Hierteenoor begin 'Kaaitjie, Katlagtertjie' met'n uitspraak wat mens amper aan 'n outydse patriarg en kerkvader laat dink: 'As vroue maar mans was. Dink net: hemel op aarde. G'n misverstand ooit tussen geslagte nie.' Maar dan besef hy gou: 'Watter mansmens wil dan nou skuurpapier teen sy wang voel en borshare tussen sy vingers as hy aan't vroetel raak?'

In 'Nimrod se strandhuis' word op kostelike wyse vertel van die ondernemingsvernuf van die tuinwerker op Bojaansbaai en hoe hy sy werkgewer uitoorlê het. Humor is inderdaad een van Van Tonder se sterk punte.

Grepe uit die geskiedenis word ook betrek in sommige vertellinge. So word daar vertel van die man wat in die Anglo-Boereoorlog in die kamp op Simonstad gesterf het nadat hy deur ' $n$ haai doodgebyt is of die staaltjie oor Paul Kruger en padwoede. Die verteller noem trouens dat die Paul Kruger van wie hy in die vroeë koerante gelees het, heeltemal anders was as die oom Paul van wie hy op skool geleer het. 'n Mens wonder inderdaad hoeveel omgangsmites rondom die ou president gekonstrueer is.

'Op soek na Karel Schoeman' is vir die literêre leser veral verkwiklik aangesien dit vir ons 'n blik werp op dié J.D. Salinger van die Afrikaanse letterkunde se tong-in-die-kieshouding teenoor diegene wat hom probeer opspoor op Trompsburg. Jan van Tonder se ligte leesstof is gemik op 'n bepaalde lesersgroep en sal in hulle smaak val. Dit is goed geskryf en gee vir ons 'n klein blik op die menslike toestand - selfs al word dit soms uit die duim gesuig of bietjie aangedik. 